\title{
FURNITURE MAKING TRAINING AS CREATIVE INTERIOR BUSINESS DEVELOPMENT IN TIRTOMOYO VILLAGE MALANG
}

\author{
Tiara Ika Widia PRIMADANI*, Bambang Kartono KURNIAWAN, Shidarta SHIDARTA \\ and Wahyu Waskito PUTRA \\ Bina Nusantara University, Indonesia \\ *tiara.primadani@binus.ac.id
}

\begin{abstract}
Funitur as a complement to the interior becomes a commodity business that promise today. Currently, almost half the Tirtomoyo village transformed into a new residential complex. Changing agricultural land into residential land makes residents who previously livelihood as farmers begin to lose their jobs. Social and economic inequality becomes a new problem for the surrounding community and migrants, if there is no cooperation between several parties to solve the problem. The target of this activity is youth groups in Tirtomoyo Village. This research method uses qualitative and experimental methods. Furnitur making training for youth groups aims to encourage the emergence of creative entrepreneurs in Tirtomoyo Village. The training activities that have been carried out are making furniture from pallets and multiplex with HPL finishing. Activities carried out by the delivery of theoretical material, direct training and mentoring the development of furniture products. Outcomes of this activities such as product shelves and desk furniture. From these training activities, participants were able to produce furniture products made of pallet wood that were more diverse than those made of multiplex with HPL finishing.
\end{abstract}

Keywords: Furniture, Training, Creative, Industry, Interior

\section{BACKGROUND}

Empowerment activities are one of the movement methods used in carrying out community development in economic, socio-cultural and educational aspects (Fajriah et al., 2018). Community empowerment is a concept of economic development that encapsulates social values. This concept reflects the new paradigm of development, which is "people centered, participatory, empowering, and sustainable" (Rikah \& Damayanti, 2020). Ability or skills can only be prepared through education, training or counseling with various methods that are adapted to the conditions and character of the community.

The creative economy is an economic concept in the new economic era that intensifies information and creativity by relying on ideas, knowledge, skills and talents, rather than human resources. The ability of human resources is the main factor in their economic activities, taking into account their potential, environmental conditions and local communities (ismurdiyahwati, 2018). The training activities furniture manufacture is a community empowerment program that aims to increase the ability and skills of youth. Karang Taruna is the target of this activity because it is an organization in the village consisting of young people. Youth has potential that can be developed because the average age is productive, creative, forward thinking, adaptable and revolutionary (Rikah \& Damayanti, 2020).

Tirtomoyo Village is located in a strategic location. This condition is due to the location of Tirtomoyo Village on the border of Malang City and Regency. The change in the function of agricultural land into residential land causes residents who previously worked as farmers to lose their jobs, so these residents have to start looking for new jobs. According to the village head of Tirtomoyo, one of the problems that residents may face is the lack of education and knowledge of youth skills. Youth organizations do not have programs and activities that become routine activities. In addition, the lack of information about skills and creativity hinders the development of youth activities in the village.

The number of new entrants to getting citizens to be more competitive in finding a job, especially if you do not have the skills and ability to work well. Job opportunities in the informal sector are only open to those who have a certain skill or expertise (Hamzah, 2020). For this reason, it is necessary to equip themselves with these skills training which can create a productive economic business. The main target of this training activity is youth groups. Because youth or the younger generation are actors who are close to the creative industry (Hasanah, 2018). Youth are also considered to have a great interest in entrepreneurship and entrepreneurial attitudes can be formed through education and training (Asfiatul, 2013).

The presence of new residential complexes and campuses also provide new business development opportunities for the community to facilitate the needs of students as well as newcomers. Boarding houses, restaurants, and shops for daily necessities have become new business opportunities for local residents. The existence of the residential complex also targeted business potential of furniture and interior decoration. Furniture and interior decoration became one needs as a complement in a new dwelling. Moreover, the development of the interior design business is increasingly promising as more people are aware of the beauty and comfort of their homes. Not only enjoyed alone, the beauty is also shared on social media through selfies with an attractive interior design background (Agustina \& Angkawijaya, 2019).

This training activity was carried out by inviting the participation of youth organizations to contribute to providing solutions to the problems faced by the people of Tirtomoyo Village. With training and mentoring youth are 
expected thereafter to be driving and help people develop their potential. Knowledge and skills from this training is expected to be utilized by the youth for the provision of community empowerment activities.

\section{METHOD}

The scope of participants in this activity is youth organizations in Tirtomoyo Village, Malang Regency. Stages activities are divided into three sections:

\section{Observation}

The activity begins with observing the socio-cultural and environmental conditions of Tirtomoyo Village. Then proceed with holding a small discussion with representatives of youth organizations and village heads. The discussion discussed the problems of the village community and the actions needed to overcome them. Types of training activities related to interior design are also suggestions from the youth organizations. Focusing on furniture and interior decoration training is an activity option that is tailored to the efforts of several residents who are also related to interior furniture and decoration. The goals of the training can develop existing businesses and form cooperation between residents in the future in entrepreneurship.

2. Preparation of Training Activities

At this stage, coordinate with the Karang Taruna Management, collecting furniture designs, preparing materials and training tools.

3. Implementation of training activities

The implementation of the activity is divided into two sessions: material and practical sessions. In the material session, participants were given insight into furniture and interior decoration made from pallet wood and with HPL finishing. In addition, it also explained the potential of the furniture and decoration business at this time. Activities are carried out with a brief explanation by the presenter.

The next session is a practice session. In this session, participants are invited to make furniture and interior decoration directly assisted by experts. The activity begins with an explanation of the introduction of materials and materials, tools and manufacturing techniques.

4. Evaluation and mentoring

The evaluation stage is carried out by distributing questionnaires about the participants' responses to the activities that have been carried out. While the mentoring phase is carried out by monitoring the impact of training activities on youth youth groups.

This furniture training activity was carried out twice:

1. Manufacture of furniture and interior decoration made of pallet wood

2. Manufacture of furniture and interior decoration made from HPL (High Pressure Laminated) finishing.

Selection of these training activities consider the environment and society. The existence of new market opportunities such as housing and student housing needs. Judging from the skills possessed by the community, previously there were residents who opened businesses related to the repair of used furniture, welders and sellers of household furniture. These skills need to be developed in accordance with the development of styles and conditions of the surrounding community. Outcome of this activity is finished furniture products are prepared on display in the showroom and promoted. After the product is displayed, promoted and then sold with a pre-order system.

\section{DISCUSSION}

\section{Training on making interior decoration made of pallet wood.}

The training was conducted for 1 day, starting at 08.00 am and finish at 16:00 pm. This activity is divided into two sessions: theoretical and workshop delivery. The training on making interior decoration made of pallet wood begins with an explanation of the theory of knowing pallet wood and various designs of pallet wood decoration. After that proceed with the introduction of equipment and materials that will be used in the workshop. The choice of pallet wood is based on the utilization of waste. Pallet wood, also known as Dutch teak, is mostly waste from packing products imported from abroad. In addition, the attractive texture and color of pallet wood are the added value of this material to be used as modern interior decoration.

In this training, the form of decoration that will be made by participants has been provided in the form of a front view image and its dimensions. Participants are divided into several groups to facilitate the distribution of equipment use. If time is still available and participants have completed the task, participants are free to be creative with the remaining materials. In addition to pallet wood, the supporting materials used are wood paint and wood glue. The equipment used is a pencil, ruler, chainsaw, sandpaper, and brush.

The results of the training, the enthusiasm of the participants was very high. It can be seen from the results of successful products are well made and produced many other forms aside from the initial design. The products produced by the participants are neat and worthy to be marketed.

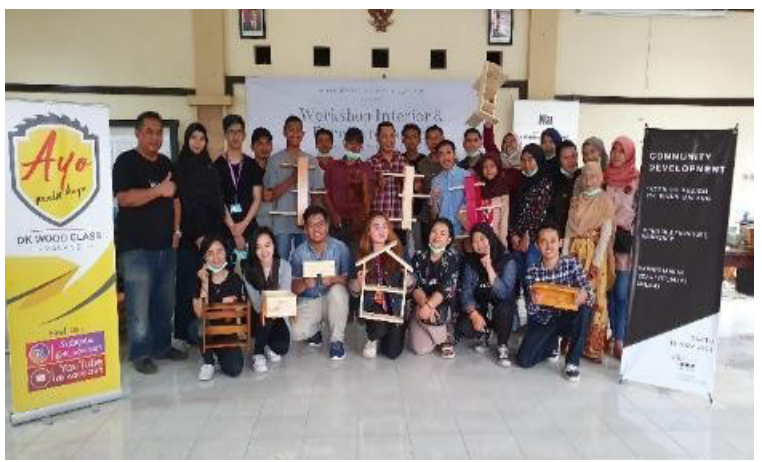

Picture 1. Participants and their work on interior decoration products made of pallet wood. 
Training on making HPL finished furniture.

This activity is carried out through several stages which are carried out over 2 days. The first stage carried out on the first day was an introduction and insight into the interior design business and especially in the field of HPL finished furniture. This activity lasted for 2 hours, containing material presentations and questions and answers. The material presented about the introduction of HPL includes the reasons for choosing HPL, its advantages and disadvantages, types of HPL, examples of HPL finishing applications in interior design and how to make HPL finishing furniture. The output of this stage, participants can get to know about HPL in interior design, its business opportunities and creative aspects.

After the participants learned about the ins and outs of HPL, the next stage was training on furniture production with HPL finishing. This activity takes place on the 2 nd day from 9.00 - 15.00 WIB. Production training is carried out directly, participants are accompanied by experts in the field of furniture production with HPL finishing. By presenting the experts, it is hoped that they can share tips and tricks in installing HPL. Although the installation of HPL is relatively easy, it requires a lot of patience and high accuracy.

The materials and equipment used for this training are 3 sheets of $18 \mathrm{~mm}$ multiplex, 3 sheets of HPL, glue, sandpaper, cutter, screw, plastic sheet, electric saw, angle ruler. The training activities carried out were: explanations from experts, reading working drawings, cutting multiplex, assembling them into furniture, pasting HPL and tidying joints. The results of the training targets : 2 wall shelves and 1 table furniture.

The high enthusiasm of the participants can be seen from they were able to complete 5 wall shelves, and 2 table furniture (pictured). Wall shelves made of $18 \mathrm{~mm}$ multiplex and HPL finishing with wood motifs. Shelf can be used as interior decoration. While the table furniture is made of $18 \mathrm{~mm}$ multiplex with HPL finish with wood motifs and metal/iron legs. The combination of table legs in the form of metal/iron material aims to provide an example of the merging or combination of two materials between HPL and iron finishing multiplex. In addition, the combination of iron materials aims to take advantage of the capabilities of residents who have opened welding services.

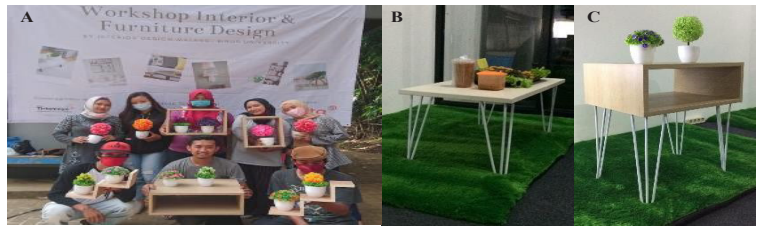

Picture 2. (A) The results of the training in the form of shelves and HPL finishing table furniture without iron legs; (B,C) A table with iron legs is on display at the Tirtomoyo Village Creative House.

Result

After the first training activity, theyouthorganizations in Tirtomoyo Village have formed an "interior design club". The club was formed so that communication between participants and assistants is maintained, and makes it easier for consultations in the development of the furniture and interior decoration business. In addition, participants will continue to hone their skills in the field of furniture production by creating joint workshops for the production of their furniture business. From the results of the questionnaire, the participants were complaints about the limited time at a workshop session. Enthusiastic participants in this training is very good, with $95 \%$ of respondents interested in attending the next training.

Based on the evaluation of the implementation of HPL-finished furniture making activities, participants experienced some difficulties in making precise frames, reading working drawings and the limited equipment used. Based on the results of the finished furniture, it still looks untidy at the ends of the HPL connection. This is quite reasonable for beginners, because the most difficult part and requires patience is the finishing part of the end of the connection between HPL. The production results of the training activities were displayed at Tirtomoyo's creative house and received good responses from the community. The response was in the form of a simple study table order.

Based on the questionnaire, $87 \%$ of the participants intend to try their hand at doing business in the production of furniture and shelves. There are several obstacles they face to start this business, namely in the areas of equipment availability, marketing, guidance from experts, ideas and creativity, and capital. $100 \%$ of the participants were also enthusiastic about participating in other training activities related to interior design in the future.

\section{CONCLUSION}

The training activity for making decorations and furniture at the youth organization in Tirtomoyo Village received a good response from the participants. This can be seen from the activity output in the form of decoration and furniture products that have exceeded the target. After going through the marketing process, the product has been successfully sold. Participants were also enthusiastic about participating in the first and second training. The formation of the 'Interior Club' for the youth organizations in Tirtomoyo Village and the plan to build a furniture workshop are a sign of the seriousness of the participants in following up on the results obtained from this training activity.

The public's response to the products resulting from this training activity was only known after the products were displayed at the Tirtomoyo creative house. Unfortunately, the interior decoration products made from pallet wood were brought home by the participants and had not been promoted so that the response of the surrounding community was not detected. From these conditions, to support the sustainability of the training and the achievement of the objectives of this activity, it is necessary to develop other training and also focus on marketing techniques. Further activities on marketing techniques and production management are needed to 
support furniture and interior decoration entrepreneurs or other creative businesses that are occupied by the Tirtomoyo Village Youth Organization.

\section{REFERENCES}

Agustina, I. A., \& Angkawijaya, Y. (2019). Fenomena Swafoto dan Pengaruhnya Terhadap Budaya Visual Pada Estetika Interior Ruang Komersial. Jurnal Desain Interior, 4(1), 37-48. https://doi. org/10.12962/J12345678.V4I1.5242

Asfiatul, F. (2013). Pengaruh Pendidikan \& Pelatihan, Prestasi Belajar Kewirausahaan terhadap Sikap Kewirausahaan Peserta didik SMK N 1 Cerme. Jurnal Kebijakan Dan Pengembangan Pendidikan, 1(2), 173- 184. https://doi.org/10.22219/JKPP. V1I2.1566

Fajriah, N., Zainal Abidin, A., Kunci, K., \& Taruna, K. (2018). Peran Karang Taruna Dalam Pemberdayaan Masyarakat (Studi Kasus di Desa Slamparejo Kecamatan Jabung Kabupaten Malang). http://riset.unisma.ac.id/index.php/rpp/ article/download/1570/1549
Hamzah, M. (2020). Efektivitas Pelatihan Keterampilan Dalam Menumbuhkan Kewirausahaan. Jurnal IKRAITH- EKONOMIKA, 3(2), 110-121.

Hasanah, L. L. N. El. (2018). Pengembangan Wirausaha Muda Ekonomi Kreatif Berbasis Budaya di Daerah Istimewa Yogyakarta. Jurnal Studi Pemuda, 4(2), 268-280. https://doi.org/10.22146/ STUDIPEMUDAUGM.36812

Ismurdiyahwati, Ika. (2018). Ekonomi Kreatif Dalam Upaya Pemberdayaan Masyarakat KampungKampung Kota Di Kecamatan Gayungan Surabaya. Majalah Ekonomi, 17(2). http:/jurnal. unipasby.ac.id/index.php/majalah_ekonomi/article/ view/1274

Rikah, \& Damayanti. (2020). Pelatihan Kewirausahaan dan Pendampingan Ekonomi Kreatif Pemanfaatan Limbah Kayu untuk Karang Taruna Gama Bina Karya Desa Tuyuhan. Seminar Nasional Abdimas Ma Chung, 231-242. https://ocs.machung.ac.id/ index.php/senam/article/view/27 